\title{
Plastyczność układu słuchowego - badania $z$ zastosowaniem metod neuroobrazowych
}

\section{Plasticity of the auditory system - studies using neuroimaging methods}

\section{Katarzyna Cieśla}

Instytut Fizjologii i Patologii Słuchu, Światowe Centrum Słuchu, Naukowe Centrum Obrazowania Biomedycznego, Kajetany

\begin{abstract}
Adres autora: Katarzyna Cieśla, Światowe Centrum Słuchu, Naukowe Centrum Obrazowania Biomedycznego, ul. Mokra 17, Kajetany, 05-830 Nadarzyn, e-mail: k.ciesla@ifps.org.pl
\end{abstract}

\section{Streszczenie}

W literaturze przedmiotu istnieją liczne doniesienia na temat zmian funkcjonalnych w obrębie układu słuchowego u dorosłych zwierząt i ludzi w okresie deprywacji słuchowej, zachodzących w wyniku rehabilitacji z użyciem specjalistycznych urządzeń wspomagających oraz w konsekwencji treningu. Zjawiska te określa się mianem „plastyczności słuchowej”. Rozwijające się w ostatnich latach techniki badań neuroobrazowych pozwalają w sposób nieinwazyjny mierzyć zakres oraz mechanizmy zmian plastycznych, zarówno w ich aspekcie czasowym, jak i lokalizacyjnym. Wprowadzenie do obszarów zastosowań tych metod stanowi temat niniejszego artykułu przeglądowego.

Słowa kluczowe: plastyczność słuchowa/plastyczność układu słuchowego • trening słuchowy • deprywacja słuchowa • implanty ślimakowe $\bullet$ badania neuroobrazowe

\begin{abstract}
Specialist literature provides vast evidence of functional changes in the auditory system in mature animals and humans, as a result of hearing deprivation, auditory rehabilitation with hearing devices and after training. These phenomena are referred to as "auditory plasticity". Due to recent advancements in neuroimaging techniques, non-invasive evaluation of temporal and spatial aspects of auditory plasticity has become possible. This review article provides an introduction to the application of these methods in auditory studies.
\end{abstract}

Key words: auditory plasticity • auditory training • hearing deprivation $\bullet$ cochlear implants $\bullet$ neuroimaging

\begin{abstract}
Wstęp
Do niedawna dominował pogląd, iż po upływie tzw. krytycznego okresu rozwoju człowieka układy zmysłowe stają się sztywne i nie mogą ulegać adaptacyjnym zmianom funkcjonalnym, a tym bardziej strukturalnym, w odpowiedzi na zachodzące w środowisku zjawiska. Wyniki współczesnych badań behawioralnych i neuroobrazowych konsekwentnie przeczą tej teorii. Najnowsze doniesienia wskazują na niewiarygodną zdolność układu nerwowego do reorganizacji na przestrzeni całego życia jednostki [1]. Również układ słuchowy charakteryzuje się znacznym potencjałem naprawczym po uszkodzeniach oraz w przypadku krótko- i długotrwałej deprywacji, jak również jest w stanie elastycznie reagować na nieznane bodźce oraz w wyniku ustrukturalizowanego treningu funkcji [2-4]. Tego typu zjawiska określa się zbiorczym terminem plastyczność układu słuchowego lub plastyczność stuchowa (ang. auditory plasticity).
\end{abstract}

Początkowo mechanizmy reorganizacji neuronalnej w obrębie układu słuchowego oceniano przede wszystkim u zwierząt, stosując metody behawioralne oraz pomiar bezpośredni odpowiedzi pojedynczych neuronów (ang. single-cell recording) [3]. Obecnie badania w tym obszarze prowadzi się również z udziałem ludzi. Stało się to możliwe przede wszystkim dzięki pojawieniu się nowoczesnych metod do badań neuroobrazowych. Stanowią one alternatywę dla inwazyjnych pomiarów funkcji układu nerwowego oraz dostarczają danych komplementarnych względem klasycznych wyników audiologicznych. Ponadto biorąc pod uwagę poziomy przetwarzania informacji słuchowej, początkowo badacze skupiali się jedynie na najwyższym piętrze analizy, tj. reorganizacji funkcjonalnej i strukturalnej w obrębie płatów skroniowych mózgu, gdzie znajduje się kora słuchowa. W ostatnim dziesięcioleciu zaczęły pojawiać się doniesienia dotyczące plastyczności w strukturach podkorowych (tj. pień mózgu), a nawet w skali molekularnej $[1,5]$. 
W związku z obszernością tematu z jednej strony i ograniczoną wielkością artykułu z drugiej, zostaną tutaj omówione jedynie najważniejsze zagadnienia dotyczące plastyczności układu słuchowego, jak również przykładowe metody badawcze i ich aplikacje.

\section{Układ słuchowy}

Złożoność zjawisk związanych z plastycznością układu słuchowego staje się bardziej zrozumiała, gdy pozna się, jakkolwiek pobieżnie, kolejne piętra analizy informacji słuchowej. W związku z tym, że dokładny opis anatomii i fizjologii układu słuchowego znacznie przekracza zakres niniejszej pracy, przedstawione zostaną jedynie podstawowe struktury i ich rola. Temat omówiono dokładnie i przejrzyście w: [6] oraz [7]. Prace te stanowią podstawowe źródło informacji zawartych w poniższym artykule.

Układ słuchowy dzieli się na część centralną i obwodową. Na tę ostatnią składają się: ucho zewnętrzne, ucho środkowe i ucho wewnętrzne. Dźwięk, przechodząc przez ucho zewnętrzne (małżowinę uszną, zewnętrzny przewód słuchowy, błonę bębenkową) oraz środkowe, ulega transformacjom, których głównym efektem końcowym jest jego ok. 20-krotne wzmocnienie. Następnie energia akustyczna przekazywana jest do ucha wewnętrznego, gdzie znajduje się tzw. błona podstawna, której ruch precyzyjnie odzwierciedla częstotliwość i intensywność dźwięku (organizacja tonotopowa oznacza, że dla każdej częstotliwości istnieje miejsce na błonie podstawnej, dla którego ta częstotliwość powoduje maksymalne wychylenie błony). W uchu wewnętrznym są również właściwe organy zmysłowe słuchu, tj. komórki rzęsate. Większość neuronów aferentnych rozpoczyna swój bieg w wewnętrznych komórkach rzęsatych, a neurony eferentne dochodzą przede wszystkim do komórek zewnętrznych. Cechy dźwięku kodowane są w postaci wzorca wyładowań neuronalnych, który w wyniku złożonych zjawisk elektryczno-chemicznych, przekazywany jest przez nerw słuchowy do kolejnych, centralnych stacji przekaźnikowych w obrębie układu słuchowego. W pniu mózgu znajdują się parzyste: jądra ślimakowe, kompleksy oliwki, jądra wstęgi bocznej oraz wzgórki dolne. Następnie dźwięk dociera do przyśrodkowych ciał kolankowatych we wzgórzu. Każda ze struktur ma ściśle określone, złożone funkcje.

Ostatni i najbardziej złożony etap analizy akustycznej ma miejsce w korze mózgowej, a dokładniej w dwustronnych płatach skroniowych, gdzie znajdują się pierwszo- i drugorzędowa kora słuchowa (zakręty Heschla). Ta ostatnia, położona w zakrętach oraz biegunach płatów skroniowych, angażuje się w przetwarzanie słuchowe bardziej złożonych bodźców słuchowych (tu zlokalizowany jest m.in. tzw. obszar Wernicke'go, tj. ogólnie mówiąc: obszar rozumienia mowy). Regiony skroniowe za pośrednictwem pęczków łukowatych są ściśle powiązane z tzw. obszarem Broca w lewej półkuli mózgowej (w uproszczeniu: obszarem produkcji mowy) oraz jego prawostronnym homologiem w przedczołowych płatach mózgu. Dokładne opisanie sieci funkcjonalnej mózgu odpowiadającej za analizę mniej i bardziej złożonych bodźców słuchowych przekracza zakres niniejszej pracy (zainteresowanego czytelnika odsyłamy do pozycji [8]).

Połączenia między obwodowymi strukturami układu słuchowego, obszarami podkorowymi oraz korą mózgową są dwukierunkowe i działają na zasadzie sprzężeń zwrotnych. W odniesieniu do najwyższych pięter analizy mówi się o pętli korowo-wzgórzowo-korowo-wzgórkowej $[4,9,10]$. W literaturze przedmiotu opisuje się zjawiska plastyczności na każdym piętrze układu słuchowego, nadal jednak wiele procesów leżących u ich podstawy pozostaje niezbadane $[6,7]$.

\section{Techniki neuroobrazowe w badaniach układu słuchowego}

Metody neuroobrazowe są coraz bardziej powszechnie stosowane w badaniach funkcji słuchowych, często jako uzupełnienie konwencjonalnej oceny audiologicznej, która opiera się na parametrach takich jak: emisje otoakustyczne, odruch strzemiączkowy, różne rodzaje audiometrii oraz, w ramach badań elektrofizjologicznych, odpowiedzi wywołane z pnia mózgu (ang. auditory brainstem responses, ABR).

Technika elektroencefalografii (EEG) wykorzystuje pomiar odpowiedzi elektrycznych układu nerwowego w stanie spoczynkowym oraz w odpowiedzi na bodźce (ang. event-related potentials, ERPs). Jako reakcje na poziomie wzgórza interpretuje się odpowiedzi o średniej latencji (pojawiają się 10-49 ms po prezentacji bodźca; ang. middle-latency-responses, MLR), a do najczęściej badanych potencjałów korowych należy kompleks komponentów wczesnych (kilkaset sekund po prezentacji). Odpowiedzi te odzwierciedlają przetwarzanie sensorycznych cech bodźca (słuchowego P1-N1-P2, wzrokowego N75-P100-N145 i innych). Komponenty późniejsze, tj. potencjał niezgodności (ang. mismatch-negativity, MMN), fala P300 oraz potencjał N400 reprezentują wyższe procesy poznawcze, tutaj przykładowo odpowiedzi na stymulację z wykorzystaniem bodźca wyróżniającego się z kontekstu [10,11].

Spokrewniona z EEG magnetoencefalografia (MEG) opiera się na ocenie pól magnetycznych towarzyszących aktywności elektrycznej mózgu, takich jak np. potencjał niezgodności w korze czołowej (ang. medial frontal negativity, MFN), który odzwierciedla negatywną ocenę emocjonalną zjawisk w otoczeniu, tj. nieprzyjemne dźwięki. MEG pozwala eksplorować odpowiedzi mózgowe w przypadku bodźców słuchowych, mowy i innych, w tym ocenę real-time reakcji kory słuchowej na dźwięki o różnej częstotliwości [3]. Ważną zaletą metod E/EEG jest ich wysoka rozdzielczość czasowa, dochodząca nawet do kilku milisekund [12].

Tomografia funkcjonalnego rezonansu magnetycznego (ang. functional magnetic resonance imaging, fMRI) wykorzystywana jest przede wszystkim do lokalizacji odpowiedzi mózgowych (a nie ich przebiegu w czasie). Metoda opiera się na pomiarze $z$ danego regionu mózgu sygnału zależnego od poziomu utlenowania krwi (ang. blood-oxygenation-level-dependent, BOLD). Przyjmuje się, że obszar, który odpowiada za określony stan lub angażuje się w wykonanie danego zadania, zużywa więcej tlenu. fMRI jest techniką, która w sposób wiarygodny pozwala ocenić odpowiedzi mózgowe na stymulację słuchową; w obrazach uwidaczniają się zróżnicowane odpowiedzi kory skroniowej w zależności od intensywności, częstotliwości, czasu trwania oraz złożoności bodźców [10]. W odniesieniu do 
metodologii badawczej, podkreśla się konieczność stosowania paradygmatów zmodyfikowanych w ten sposób, aby zminimalizować wpływ hałasu pracy skanera (ok. $100 \mathrm{~dB}$ SPL) na aktywacje mózgowe. Technika MRI pozwala ponadto obrazować tkankę mózgową oraz anatomię kości skroniowej z rozdzielczością przestrzenną obrazu rzędu kilku milimetrów. To ostatnie zastosowanie nie stanowi jednak tematu niniejszej pracy.

W badaniach nad lokalizacją procesów centralnego przetwarzania słuchowego stosuje się również tomografię emisyjną pojedynczych fotonów (ang. single-photon emission computed tomography, SPECT) oraz pozytonową tomografię emisyjną (ang. positron emission tomography, PET). Metody te pozwalają m.in. na ocenę regionalnego przepływu krwi (SPECT i PET) oraz zmian metabolicznych (tylko PET) wynikających z zaangażowania danego obszaru mózgu w realizację funkcji poznawczej, takiej jak np. analiza słuchowa [13,14]. PET/SPECT są jedynymi neuroobrazowymi technikami lokalizacyjnymi używanymi obecnie do analizy aktywacji słuchowych u osób korzystających z implantów ślimakowych (urządzenia wszczepiane do ucha wewnętrznego w przypadkach ciężkich niedosłuchów odbiorczych). Implanty wykluczają udział pacjenta w badaniu fMRI o silnym polu magnetycznym, ze względu na właściwości magnetyczne urządzeń [15].

Techniki rzadziej używane w badaniach nad plastycznością układu słuchowego to przezczaszkowa stymulacja magnetyczna (ang. transcranial magnetic stimulation, TMS), która polega na wywoływaniu depolaryzacji neuronów w korze mózgowej oraz przezczaszkowa stymulacja stałoprądowa (ang. transcranial direct stimulation, tDCS), której zastosowanie ma na celu zmianę częstości wyładowań elektrycznych neuronów. Do tej pory metody te były eksperymentalnie wykorzystywane w leczeniu m.in. szumów usznych [16].

Każda z opisanych metod neuroobrazowych dostarcza swoistych informacji dotyczących hipotezy, którą stara się zweryfikować badacz. W zależności od celu badania, dana technika może być bardziej odpowiednia. Przykładowe aplikacje w obszarze badań nad plastycznością układu słuchowego zostaną przedstawione dalej.

\section{Plastyczność układu słuchowego}

\section{Poziom molekularny}

Wyniki najnowszych badań wskazują, iż zmiany plastyczne mogą mieć miejsce na każdym poziomie drogi słuchowej, zarówno w odniesieniu do stopnia zaawansowania struktury biologicznej, jak i pięter przetwarzania słuchowego [2-4]. Najniższy poziom neuroplastyczności dotyczy zjawisk molekularnych oraz warunkowania komórkowego, tj. zmian w obrębie pól receptorowych pojedynczych neuronów w odpowiedzi na zjawiska zachodzące w otoczeniu akustycznym [1,17]. W większości przypadków oznacza to modyfikacje na poziomie reprezentacji synaptycznych, tj. zmiany siły odpowiedzi neuronalnych lub ilości komórek nerwowych zaangażowanych w przetwarzanie bodźców, w zależności od ich wartości behawioralnej [18]. Mechanizmy tych zjawisk wyjaśnia „uczenie się wg zasad Hebba", która to teoria zakłada, iż wzmocnieniu ulegają połączenia synaptyczne między neuronami, które często razem reagują, co przekłada się na obserwację, iż czułość układu nerwowego wzrasta w przypadku bodźców skorelowanych czasowo (długotrwałe wzmocnienie synaptyczne, ang. long-term potentiation, LTP, oraz długotrwałe osłabienie synaptyczne, LTD) [5,19]. Zmieniona stymulacja zmysłowa może ponadto wywołać modyfikacje strukturalne w obrębie układu słuchowego, takie jak np. zmiana położenia aksonów oraz zasięgu dendrytów (a w konsekwencji zmianę objętości istoty białej w danym regionie mózgu) [19,20]. W zależności od cech środowiska akustycznego, subiektywnej wartości bodźca oraz kondycji układu słuchowego, zmiany plastyczne na poziomie molekularnym mogą być krótko- lub długotrwałe [17].

Większość badań układu słuchowego na poziomie molekularnym prowadzona jest na zwierzętach, z zastosowaniem technik inwazyjnych. Jest to temat relatywnie nowy i dokładne mechanizmy reorganizacji układu słuchowego na poziomie komórkowym nie są jeszcze poznane. Odnosi się to w szczególności do propagacji map tonotopowych między błoną podstawną w ślimaku a pierwotną korą słuchową w płatach skroniowych mózgu $[21,22]$.

\section{Złożone struktury układu słuchowego}

Większość badań z zastosowaniem technik neuroobrazowych koncentruje się na funkcjach kory mózgowej oraz strukturach w jej obrębie, tj. płatach, zwojach i bruzdach. Nieliczne eksperymenty dotyczą niższych poziomów przetwarzania informacji słuchowej. Opisywane są dwa podstawowe mechanizmy, które leżą u podłoża plastycznej reorganizacji neuronalnej: (a) uczenie się percepcyjne oraz (b) deprywacja słuchowa. W dalszej części niniejszej pracy przedstawione zostaną wyniki przykładowych klasycznych badań z tego obszaru.

\section{Plastyczność w wyniku uczenia się [ang. use-dependent plasticity]}

Plastyczne zmiany o krótko- lub długotrwałych efektach w obrębie układu słuchowego mogą być następstwem uczenia się percepcyjnego, biernej ekspozycji lub treningu z zastosowaniem określonych bodźców słuchowych.

Grupa Recanzone i wsp. prowadziła pionierskie badania plastyczności kory słuchowej z zastosowaniem pomiaru odpowiedzi pojedynczych neuronów u makaków, które przez kilka tygodni trenowano w rozpoznawaniu częstotliwości dźwięku. Wykazano powiększenie tonotopowej reprezentacji neuronalnej w pasmach częstotliwości, który były najintensywniej wzmacniane [23]. Dinse i wsp. przedstawili podobne wyniki, a ponadto wskazywali na podwyższoną synchronizację neuronalną w pasmach częstotliwości, które wzmacniano przez kilka miesięcy u kota za pomocą stymulacji za pośrednictwem implantów ślimakowych [5]. Weinberger i wsp. stwierdzili, że nawet w głębokiej anestezji warunkowe sprzężenie dwóch tonów powoduje przesunięcie mapy tonotopowej w pierwotnej korze słuchowej u świnek morskich [24].

Przykładowe badania z udziałem osób z normalnym słuchem prowadzono $\mathrm{z}$ wykorzystaniem otoemisji akustycznych oraz odpowiedzi wywołanych z pnia mózgu. 
Analizując zmiany w rejestrowanych odpowiedziach w wyniku treningu, zasugerowano kluczową rolę pęczka oliwkowo-ślimakowego $\mathrm{w}$ procesie uczenia się percepcyjnego dyskryminacji fonemów. Obszar ten odpowiada za regulację progu i wielkości pobudzenia, a w konsekwencji determinuje wzmacnianie nowych reprezentacji dźwiękowych w korze słuchowej. Odpowiedzi w obrębie pęczka na początku treningu okazały się doskonałym predyktorem jego efektów (im mniejsze odpowiedzi, tym większe efekty), a ich amplituda zwiększała się istotnie w przypadku poprawy w poziomie wykonania w zadaniach behawioralnych [9].

Dowodów na istnienie krótkotrwałej plastyczności układu słuchowego dostarczają badania elektro- i magnetoencefalograficzne odpowiedzi korowych. Okazuje się, że kora słuchowa może ulegać reorganizacji już w wyniku kilkugodzinnego treningu z zastosowaniem bodźców o różnych zakresach częstotliwości [25]. Badania fMRI grupy Jaencke i wsp. wskazują, że trening rozróżniania częstotliwości powoduje poprawę wyników na poziomie behawioralnym, jak również ogranicza zaangażowanie w zadanie odpowiednich struktur słuchowych takich jak górny zakręt skroniowy oraz biegun kory skroniowej [18]. Inne eksperymenty z zastosowaniem słuchowych potencjałów wywołanych sugerują zjawisko odwrotne - zwiększone zaangażowanie danego obszaru kory słuchowej w przypadku krótkotrwałego treningu funkcji. Ma na to wskazywać większa amplituda wywołanych odpowiedzi mózgowych. Wyniki badań są komplementarne i wskazują, iż różne metody eksperymentalne odnoszą się do różnych poziomów i aspektów przetwarzania słuchowego (NB różna rozdzielczość czasowa technik fMRI i EEG) [1,3].

W odniesieniu do długotrwałej reorganizacji słuchowej, badania z zastosowaniem potencjałów wywołanych prowadzi się u profesjonalnych muzyków. Wykazują oni wyższe amplitudy odpowiedzi z mózgowych obszarów odpowiedzialnych za przetwarzanie bodźców słuchowych oraz słuchowo-wzrokowych w korze i w pniu mózgu w odpowiedzi na bodźce słowne i muzykę, w porównaniu z osobami bez doświadczenia muzycznego. Krótsze latencje i wyższe amplitudy stwierdza się u muzyków już w momencie rozpoczęcia stymulacji, co sugeruje zwiększoną swoistą synchronizację neuronalną w tej grupie $[26,27]$.

Inne badania nad długotrwałą plastycznością słuchową w wyniku uczenia się dotyczą nabywania języka ojczystego. Na przykład Krishnan i wsp. w eksperymentach z zastosowaniem potencjałów wywołanych wykazali, że percepcja wysokości dźwięku u użytkowników języków zachodnich jest funkcją w dużej mierze prawopółkulową, natomiast u osób, których ojczystym językiem jest mandaryński, dominująca dla tej funkcji jest półkula lewa. Odkrycie to związane jest prawdopodobnie $\mathrm{z} \mathrm{w}$ faktem, iż w języku mandaryńskim wysokość dźwięku posiada dodatkową wartość semantyczną. Ponadto istnieją doniesienia, iż w zadaniach językowych synchronizacja fal mózgowych jest podwyższona dla częstotliwości typowych dla języka natywnego dla osoby badanej, w porównaniu z przetwarzaniem bodźców w języku obcym [28], por. [29] - praca poglądowa.

Elektroencefalografia $\mathrm{z}$ zastosowaniem wywołanych potencjałów słuchowych oraz tomografia funkcjonalnego rezonansu magnetycznego wydają się metodami preferowanymi w badaniach nad plastycznością zdrowego układu słuchowego, coraz częściej towarzysząc konwencjonalnym badaniom audiologicznym. Metody PET i SPECT wiążą się z bardzo wysokimi kosztami eksploatacji oraz narażeniem pacjenta na promieniowanie. Możliwość ich rutynowego zastosowania jest bardzo ograniczona.

\section{Plastyczność słuchowa w wyniku deprywacji}

Deprywacja słuchowa może prowadzić do zmian plastycznych w obrębie układu słuchowego. Większość badań dotyczących tego zagadnienia obejmuje określone grupy pacjentów, przede wszystkim: osoby z jednostronną głuchotą, osoby obustronnie głuche $\mathrm{z}$ jednostronnymi aparatami słuchowymi, użytkowników implantów ślimakowych oraz osoby z szumami usznymi. Ponadto zdarzało się, iż u osób $\mathrm{z}$ normalnym poziomem słyszenia eksperymentalnie manipulowano doświadczeniem słuchowym. Aby ocenić efekty fizjologiczne deprywacji słuchowej, stosuje się przede wszystkim potencjały wywołane z pnia mózgu (ABRs) oraz z kory (CEAPs). Badania poszerza się czasem o ocenę zjawisk percepcyjnych, takich jak progi tolerancji głośności (ang. uncomfortable loudness levels, ULLs) oraz testy rozpoznawania mowy [30]. W celu lokalizacji funkcjonalnych zmian plastycznych, specjaliści stosują przede wszystkim fMRI oraz PET.

\section{Głuchota jednostronna}

W grupie osób z głuchotą jednostronną nieliczne do tej pory eksperymenty fMRI wskazują na symetryczne aktywacje obu półkul w odpowiedzi na stymulację jednostronną, w przeciwieństwie do normalnie słyszących osób, u których odpowiedzi mózgowe stwierdza się przede wszystkim w półkuli kontralateralnej do stymulacji $[31,32]$. Podobnych wyników świadczących o odmiennych wzorcach odpowiedzi korowych dostarczają badania słuchowych potencjałów wywołanych, gdzie wskazuje się na podwyższoną koherencję międzypółkulową u pacjentów $\mathrm{z}$ niedosłuchem $\mathrm{w}$ porównaniu $\mathrm{z}$ normalnie słyszącymi osobami [33]. Jako mechanizm wyjaśniający sugeruje się obniżone hamowanie odpowiedzi w półkuli ipsilateralnej do stymulacji oraz zmiany w odniesieniu do lateralizacji funkcji słuchowych, wynikające z okresu deprywacji. $\mathrm{Z}$ drugiej strony, istnieją również doniesienia z badań ERP świadczące o braku jakichkolwiek zmian elektrycznej aktywności mózgu specyficznych dla głuchoty jednostronnej [34]. Tego typu obserwacje mogą sugerować znaczną heterogeniczność w obrębie grupy; wydaje się, że dla organizacji ścieżek słuchowych krytyczny jest moment życia, w którym pojawiła się głuchota [13]. Badań neuroobrazowych poświęconych głuchocie jednostronnej jest bardzo niewiele, choć ich wyniki mogłyby mieć potencjalnie dużą wartość w odniesieniu do planowania optymalnej zindywidualizowanej rehabilitacji pacjenta.

\section{Aparaty słuchowe}

Możliwym sposobem poprawienia jakości życia osoby $\mathrm{z}$ niedosłuchem jest korzystanie $\mathrm{z}$ aparatu słuchowego. Najnowszy kierunek badań nad plastycznością słuchową w grupie osób z niedosłuchem obustronnym, korzystających z jednostronnych aparatów słuchowych dotyczy 
„efektu aklimatyzacji” [35]. Dotychczasowe wyniki wskazują, iż w przypadku prezentacji bodźca do ucha, które wyposażone jest w aparat, bardziej skutecznie przetwarzane są bodźce mowy o dużej intensywności; gdy natomiast stymulowane jest ucho bez wzmocnienia, bodźce o niskiej intensywności są analizowane bardziej efektywnie. Ponadto doświadczenie korzystania $\mathrm{z}$ aparatu słuchowego okazuje się zwiększać tolerancję dla głośnych bodźców. Zjawisko to jest niezależne od rodzaju treningu słuchowego [36]. Munro i wsp. [37] proponują ponadto termin tzw. "późnej głuchoty” dla zjawiska postępującego pogorszenia w testach rozpoznawania mowy w uchu bez aparatu, co może sugerować, iż dźwięki, które docierają do ucha bez wzmocnienia, są traktowane jako mniej istotne i ulegają degradacji. Inne badania elektrofizjologiczne wskazują na istotną korelację między poprawą wyników w audiometrii tonalnej, skróceniem latencji (czas od pojawienia się bodźca) oraz wzrostem amplitudy odpowiedzi z pnia mózgu w uchu ze wzmocnieniem. Jest to dowód na to, że poszczególne piętra układu słuchowego stanowią integralną całość, która może ulegać zmianom w wyniku sztucznej amplifikacji [2]. Formby i wsp. sugerują podobne efekty plastycznych zmian słuchowych u osób z normalnym poziomem słyszenia, a mianowicie podwyższoną czułość na intensywność dźwięku oraz obniżony próg odruchu strzemiączkowego u osób wyposażonych w jednostronne zatyczki do uszu oraz obniżoną wrażliwość u uczestników badania z włożonymi do ucha generatorami szumu [36,38].

Technika fMRI pozwala śledzić odpowiedzi mózgowe u osób z aparatami słuchowymi, ale tylko wtedy, gdy pacjent na czas badania wyjmie aparaty z uszu (ze względu na artefakty w obrazie MRI, które powstają w związku $\mathrm{z}$ obecnością w aparacie elementów magnetycznych). Jedno $\mathrm{z}$ nielicznych eksperymentów podłużnych fMRI wskazuje, że w trzy miesiące po zastosowaniu lewo- lub prawostronnego aparatu słuchowego odpowiedzi mózgowe na prezentację mowy maleją obustronnie w korze słuchowej. Po dziewięciu miesiącach w wyniku stymulacji ucha wyposażonego w aparat odbudowuje się wzorzec odpowiedzi lewostronnych dla mowy [39]. Wyniki sugerują, że wraz z doświadczeniem odpowiedzi mózgowe stają się coraz bardziej zbliżone do normalnego wzorca. Ponadto m.in. Skarżyński i wsp. [40] stwierdzili plastyczne zmiany w obrębie mapy tonotopowej w pierwotnej korze słuchowej u pacjentów z częściową głuchotą korzystających z obustronnych aparatów słuchowych; wzorce korelowały z wynikami indywidualnych audiogramów tonalnych w wybranych pasmach częstotliwości.

Wyniki nielicznych badań SPECT/PET również interpretuje się jako świadczące o reorganizacji w obrębie kory mózgowej w wyniku deprywacji słuchowej. Wzorzec odpowiedzi uzależniony jest od etiologii, rodzaju i długości trwania niedosłuchu, doświadczenia $\mathrm{z}$ aparatami słuchowymi oraz stosowanych metod komunikacji (czytelników odsyłamy do pracy poglądowej [13]).

\section{Implanty ślimakowe}

Implanty ślimakowe są obecnie standardową interwencją w przypadku znacznego lub ciężkiego niedosłuchu pochodzenia odbiorczego (uszkodzenie w obrębie ucha wewnętrznego). Istnieją badania u zwierząt i ludzi wskazujące, iż w przypadku lezji ślimaka mapa tonotopowa słuchowej kory pierwotnej ulega zmianom plastycznym. Okazuje się między innymi, iż neurony korowe kodujące częstotliwości dźwięku, za które „odpowiada” uszkodzona część ślimaka (w związku z wzorem odpowiedzi błony podstawnej), zaczynają reagować na stymulację z użyciem tonów o częstotliwościach graniczących z obszarem uszkodzenia (ang. cut-off frequencies). W związku $\mathrm{z}$ tym reprezentacja tych częstotliwości w korze (i we wzgórzu) się rozrasta [41].

Również eksperymenty z zastosowaniem potencjałów wywołanych z udziałem ludzi wskazują na podwyższoną amplitudę potencjału niezgodności w obrębie częstotliwości granicznych [42]. Według Gabriel i wsp. prostym wyjaśnieniem tego zjawiska jest odmaskowanie odpowiedzi niespecyficznych dla określonych komórek słuchowych w wyniku deprywacji sąsiednich receptorów, co w konsekwencji może prowadzić do generalizacji zmian plastycznych, również na reprezentację ucha kontrlateralnego do stymulacji [43]. Badacze nie są zgodni co do efektów „przejmowania częstotliwości” w kontekście poziomu rozpoznawania mowy w niedosłuchu. Sprzeczne wyniki sugerują lepsze [44] lub gorsze [45] wyniki w przypadku stymulacji o częstotliwościach granicznych. Na poziomie podkorowym badania z wykorzystaniem pomiaru odpowiedzi pojedynczych neuronów wskazują, że uszkodzenie ślimaka wywołuje podwyższoną aktywację w jądrach ślimaka, wzgórku dolnym [oraz pierwotnej korze słuchowej], co odzwierciedla integralność wszystkich pięter układu słuchowego, a w tym przypadku efekt desynchronizacji [19].

Tomografia emisyjna jest metodą badawczą z wyboru u pacjentów wyposażonych w implanty ślimakowe. W związku z elementami magnetycznymi obecnymi w protezie, które w skanerze fMRI mogą migrować, nagrzewać się, a ponadto powodować znaczne artefakty w obrazie, nie przeprowadza się takich badań, za wyjątkiem skanerów o bardzo niskim polu magnetycznym [15]. Eksperymenty z udziałem osób z implantami ślimakowymi z wykorzystaniem SPECT/PET zdają się sugerować, że proces uczenia się mózgu po zabiegu to przykład adaptacji słuchowej oraz opracowywania optymalnych strategii poznawczych, a nie tylko próba odtworzenia wzorców charakterystycznych dla zdrowej kory słuchowej $[5,44,46]$. U użytkowników implantów jednostronnych (a takich jest większość) podstawowe obserwacje dotyczące zmian plastycznych w obrębie mózgu wskazują na: (a) znacznie większe aktywacje w obszarze pierwotnej kory słuchowej w tej populacji [47], (b) niejednorodne wzorce lateralizacji słuchowej [48], (c) podwyższony metabolizm spoczynkowy glukozy w regionach odpowiedzialnych za przetwarzanie mowy w przypadku głuchoty prelingwalnej (powstałej przed rozwojem mowy i języka) [49], (d) zmieniony wzorzec odpowiedzi mózgowych w korze skroniowej i czołowej u osób z głuchotą postlingwalną (powstałą po rozwoju mowy i języka) (kwestie te omówiono szczegółowo w pracy poglądowej [13]). U osób z implantami ślimakowymi wszczepionymi obustronnie stwierdza się, iż aktywacje słuchowe na poziomie kory zbliżają się do normy po implantacji drugiego urządzenia oraz wraz z nabywaniem doświadczenia. Istotny okazuje się również czas trwania niedosłuchu [48,50]. Wyzwaniem i tematem coraz większej liczby prac jest obecnie określenie wzorców aktywacji mózgowej, które mogłyby posłużyć jako predyktory poziomu rozumienia mowy 
po implantacji ślimakowej. Pozwoliłoby to być może wyjaśnić znaczne zróżnicowanie w wynikach testów rozumienia mowy wśród użytkowników tych urządzeń $[51,52]$.

\section{Szumy uszne}

Istnieją doniesienia, iż zmiany plastyczne w obrębie układu słuchowego zachodzą również w przypadku szumów usznych, które przez pacjentów opisywane są jako „proste halucynacje słuchowe", tj. brzęczenie, szumienie, gwizdanie. Szumy często współwystępują z niedosłuchem pochodzenia odbiorczego. Badania elektrofizjologiczne wskazują, iż często dominujące pasma częstotliwości są wspólne dla obu zaburzeń, co mogłoby sugerować występowanie zjawiska wzmocnienia czułości układu słuchowego w obszarze częstotliwości granicznych dla obszaru wirtualnej lezji w pierwotnej korze słuchowej $[19,41]$. W celu zmniejszenia sugerowanej nadpobudliwości kory słuchowej u pacjentów z szumami, Eichhammer i wsp. zastosowali przezczaszkową stymulację magnetyczną o niskich częstotliwościach. W wyniku interwencji intensywność szumów usznych obniżyła się, a niedosłuch nie uległ pogorszeniu [16]. Kilka badań fMRI wykazało specyficzną dla pacjentów z szumami usznymi reorganizację map tonotopowych w słuchowej korze pierwotnej oraz zmienione wzorce połączeń wzgórzowo-korowych. Ze względu na bardzo różnorodną etiologię (m.in. częstą rolę komponentów psychologicznych) i przebieg szumów, niewielu badaczy podejmuje się badań nad tym zagadnieniem [19].

\section{Wnioski}

Techniki neuroobrazowe stanowią nowy ważny element badań nad mechanizmami plastyczności układu słuchowego. Nadal próbuje się opisać standardowe odpowiedzi układu słuchowego na szereg bodźców, jak również wzorce „zaburzone” oraz ponad-normalne (np. zmienione odpowiedzi słuchowe u wykształconych muzyków), biorąc pod uwagę lokalizację i lateralizację funkcji (fMRI i PET), przepływ krwi i metabolizm glukozy w korze mózgowej (SPECT i PET) oraz charakterystykę odpowiedzi elektrofizjologicznych (EEG i MEG).

Liczne badania demonstrują plastyczne efekty ekspozycji na nowe dźwięki i trening na wszystkich poziomach drogi słuchowej, dostarczając m.in. dowodów potwierdzających korzyści z aparatów słuchowych oraz implantów ślimakowych w grupie osób $\mathrm{z}$ niedosłuchem, jak również wskazując na potrzebę odpowiedniej rehabilitacji słuchowej po zastosowaniu interwencji medycznej. W przyszłości wieloaspektowe badania podłużne wydają się niezbędne do monitorowania zmian w obrębie układu słuchowego, jako funkcji długości trwania ekspozycji na dany rodzaj bodźców oraz długości trwania niedosłuchu. Pozwoliłoby to przede wszystkim rozróżnić zmiany spowodowane utratą sprawności oraz zmiany związane stricte $z$ interwencjami audiologicznymi i operacyjnymi.

Tematem, który jest obecnie często poruszany w badaniach neuroobrazowych, jest zjawisko komplementarnej reorganizacji funkcjonalnej w obrębie kilku mózgowych regionów sensorycznych w populacji z zaburzeniami słuchu (ang. cross-plasticity). Najwięcej doniesień dotyczy przetwarzania bodźców słuchowych przez obszar, który u osób normalnie słyszących odpowiada za analizę wzrokową (kora wzrokowa) oraz bodźców wzrokowych w obrębie kory słuchowej. W zależności od czynników, takich jak np. długość trwania niedosłuchu, zmiany tego typu $\mathrm{w}$ różny sposób wpływają na funkcjonowanie pacjenta. W związku z tym, że temat ten przekracza zakres artykułu, czytelnika odsyłamy do pracy poglądowej [49].

Wydaje się, że obecnie można wskazać trzy podstawowe wyzwania metodologiczne w obszarze badań nad plastycznością układu słuchowego: (a) rozwój metod do traktografii istoty białej, które pozwoliłyby w sposób jednoznaczny określić sieć strukturalnych połączeń nerwowych między korą słuchową i pozostałymi obszarami mózgu oraz metod statystycznych do oceny tzw. połączeń „funkcjonalnych” w obrębie sieci mózgowych (wzmacniane $\mathrm{w}$ przypadku wspólnego zaangażowania $\mathrm{w}$ zadanie) ([13] - praca poglądowa), (b) analiza stanu spoczynkowego mózgu m.in. w populacji z niedosłuchem (ang. resting-state) [53], (c) opracowanie metodologii badań molekularnych PET i pharmaco-MRI (ocena odpowiedzi mózgowych po zastosowaniu interwencji farmakologicznych) do oceny wpływu modulacji chemicznych z zastosowaniem neuroprzekaźników, takich jak dopamina, serotonina, acetylocholina, na funkcje słuchowe [54].

W związku z faktem, iż bezpośrednia inwazyjna ocena struktur i funkcji układu słuchowego jest u człowieka niemożliwa (za wyjątkiem operacji neurochirurgicznych), metody neuroobrazowe mają ogromną wartość kliniczną i naukową. Jedynie dzięki zastosowaniu tych technik jesteśmy w stanie zbliżyć się do poznania złożonych mechanizmów plastyczności w obrębie układu słuchowego, zarówno w celu opracowania optymalnych metod treningu i rehabilitacji słuchowej, jak i dla ogólnego zrozumienia zjawisk reorganizacji układu nerwowego.

\section{Piśmiennictwo:}

1. Irvine DRF, Fallon JB, Kamke MR. Plasticity in the adult central auditory system. Acoustics Australia, 2009; 34(1): 13-17.

2. Illing RB. Activity-Dependent Plasticity in the Adult Auditory Brainstem. Audiol Neurootol, 2001; 6(6): 319-45.

3. Neuman AC. Central auditory system plasticity and aural rehabilitation of adults. J Rehabil Res Dev, 2005; 42(4): 169-86.

4. Xiong Y, Zhang Y, Yan J: The neurobiology of sound-specific auditory plasticity: A core neural circuit. Neurosci Biobehav Rev, 2009; 33(8): 1178-84.
5. Dinse HR, Godde B, Reuter G, Cords SM, Hilger T. Auditory cortical plasticity under operation: reorganization of auditory cortex induced by electric cochlear stimulation reveals adaptation to altered sensory input statistics. Speech and Communication, 2003; 41(1): 201-19.

6. Moore BCJ. Wprowadzenie do psychologii słyszenia. Warszawa-Poznań: Wydawnictwo Naukowe PWN; 1999.

7. Hamill T, Price L. The Hearing Sciences. San Diego: Plural Publishing Inc.; 2008. 
9. De Boer J, Thornton RD. Neural Correlates of Perceptual Learning in the Auditory Brainstem: Efferent Activity Predicts and Reflects Improvement at a Speech-in-Noise Discrimination Task. J Neurosci, 2008; 28(19); 4929-37.

10. Cahill L. Cortical responses to speech stimuli in hearing impaired infants measured by fMRI and auditory evoked potentials [Doctoral Dissertation], 2010 [Retrieved from: http://etd.ohiolink.edu/view.cgi?acc_num=ucin1273174165 on May 23 2011.].

11. Banai K, Nicol T, Zecker, SG, Kraus N. Brainstem Timing: Implications for Cortical Processing and Literacy. J Neurosci, 2005; 25(43): 9850-57.

12. Martin B, Tremblay K, Stapells D. Principles and applications of cortical auditory evoked potentials. W: Burkard R, Eggermont J, Don M, red. Auditory evoked potentials: Basic principles and clinical application. Lippincott Williams \& Wilkins; 2006, 482-507.

13. Green KM. Cortical activity in cochlear implant users - a PET study, Awarded Doctorate of Medicine, University of Manchester, 2007.

14. Carera-Paz FJ, Arbizu J, Prieto E, Manrique M. PET study of auditory plasticity: Helping to address decision making for cochlear implantation of adults. SAUM, 2009; 7(1): 47-54.

15. Teissl C, Kremser C, Hochmair ES, Hochmair-Desoyer IJ. Magnetic resonance imaging and cochlear implants: compatibility and safety aspects. J Magn Reson Imaging, 1999; 9(1): 26-38.

16. Eichhammer P, Kleinjung T, Landgrebe M, Hajak G, Langetuth B. TMS for treatment of chronic tinnitus - neurobiological effects. Prog Brain Res, 2007; 166: 369-75.

17. Zatorre RJ. There's more to auditory cortex than meets the ear. Hear Res, 2007; 229(1-2): 24-30.

18. Jäncke L, Gaab N, Wüstenberg T, Scheich H, Heinze H-J. Short-term functional plasticity in the human auditory cortex: an fMRI study. Brain Res Cogn Brain Res, 2001; 12(3): 479-85.

19. Noreña AJ. An integrative model of tinnitus based on a central gain controlling neural sensitivity. Neurosci Biobehav Rev, 2011; 35(5): 1089-109.

20. Clapp WC, Hamm JP, Kirk IJ, Teyler TJ. Translating Long-Term Potentiation from Animals to Humans: A Novel Method for Noninvasive Assessment of Cortical Plasticity. Biol Psychiatry, 2012; 71(6): 496-502.

21. Buonomano DV. Cortical Plasticity: From Synapses to Maps. Annual Reviews of Neuroscience, 1998; 21: 149-186.

22. Liu XP, Basavaraj S, Krishnan R, Yan J. Contributions of the thalamocortical system towards sound-specific auditory plasticity. Neurosci Biobehav Rev, 2011; 35(10): 2155-61.

23. Recanzone GH, Schreiner CE, Merzenichet MM. Plasticity in the frequency representation of primary auditory cortex following discrimination training in adult owl monkeys. J Neurosci, 1993; 13(1): 87-103.

24. Weinberger NM, Javid R, Lepan B. Long-term retention of learning-induced receptive-field plasticity in the auditory cortex. Proc Natl Acad Sci USA, 1993; 90: 2394-98.

25. Menning H, Roberts LE, Pantev C. Plastic changes in the auditory cortex induced by intensive frequency discrimination training. NeuroReport, 2000; 11: 817-22.

26. Pantev C, Ross B, FujiokaT, Trainor LJ, Schulte M, Schulz M. Music and learning-induced cortical plasticity. Ann NY Acad Sci, 2003; 999: 438-50.

27. Musacchia G, Sams M, Skoe E, Kraus N. Musicians have enhanced subcortical auditory and audiovisual processing of speech and music. Proc Natl Acad Sci USA, 2007; 104(40): 15894-98.

28. Krishnan A, Xu Y, Gandour J, Cariani P. Encoding of pitch in the human brainstem is sensitive to language experience. Brain Res Cog Brain Res, 2005; 25(1): 161-68.
29. Friederici $\mathrm{AD}$, Wartenburger I. Language and brain. Willey Interdisciplinary Reviews - Cognitivr Science, 2010; 1(2): $150-59$.

30. Munro KJ. Reorganization of the Adult Auditory System: Perceptual and Physiological Evidence From Monaural Fitting of Hearing Aids. Trends Amplif, 2008; 12: 254-71.

31. Ponton CW. Plasticity in the adult human central auditory system: evidence from late-onset profound unilateral deafness. Hear Res, 2001; 154: 32-44.

32. Moore DR, Devlin JT, Raley J, Tunbridge E, Lanary K, Floyer-Lea A i wsp. Effects of Long Term Unilateral Hearing Loss on the Lateralization of fMRI Measured Activation in Human Auditory Cortex. Plasticity and Signal Representation in the Auditory System, 2005: 335-46.

33. Scheffler K, Bilecen D, Schmid N, Tschopp K, Seelig J. Auditory cortical responses in hearing subjects and unilateral deaf patients as detected by functional magnetic resonance imaging. Cereb Cortex, 1998; 8(2): 156-63.

34. Hine J, Roger T, Davis A. Does long-term unilateral deafness change auditory evoked potential asymmetries? Clin Neurophysiol, 2008; 119(3): 576-86.

35. Philibert L, Colleti JF, Veuillet V. The auditory acclimatization effect in sensorineural hearing-impaired listeners: Evidence for functional plasticity. Hear Res, 2005; 205(1-2): 131-42.

36. Hamilton A, Munro KJ. Uncomfortable loudness levels in experienced unilateral and bilateral hearing aid users: Evidence of adaptive plasticity following asymmetrical sensory input? Int J Audiol, 2010; 49: 667-71.

37. Munro KJ, Lutman M. The effect of speech presentation level on measurement of auditory acclimatization to amplified speech. J Acoust Soc Am, 2003; 114(1): 484-95.

38. Formby C, Sherlock LP, Gold SL. Adaptive plasticity of loudness induced by chronic attenuation and enhancement of the acoustic background. J Acoust Soc Am, 2003; 114: 55-58.

39. Hwang JH, Wu CW, Chen JH, Liu TC. Changes in activation of the auditory cortex following long-term amplification: an fMRI study. Acta Otolaryngol, 2006; 126(12): 1275-81.

40. Skarzynski H, Wolak T, Pluta A, Lewandowska M, Rusiniak M, Lorens A i wsp. Functional Magnetic Resonance Imaging of Auditory Cortex in Partial DeafnessTreatment. Journal of Hearing Science, 2012; 2(2): OA53-60.

41. Tai-Van H, Micheyl C, Norena A, Veuillet E, Gabriel D, Colleti $\mathrm{L}$. Enhanced frequency discrimination in hearing-impaired individuals: a review of perceptual correlates of central neural plasticity induced by cochlear damage. Hear Res, 2007; 233(12): $14-22$.

42. Dietrich V, Nieschalk M, Stoll W, Rajan R, Pantev A. Cortical reorganization in patients with high frequency cochlear hearing loss. Hear Res, 2001;158(1-2): 95-101.

43. Gabriel D, Veuillet E, Vesson JF, Colle L. Rehabilitation plasticity: Influence of hearing aid fitting on frequency discrimination performance near the hearing-loss cut-off. Hear Res, 2006; 213(1-2): 49-57.

44. Kluk K, Moore B. Dead regions in the cochlea and enhancement of frequency discrimination: Effects of audiogram slope, unilateral versus bilateral loss, and hearing-aid use. Hear Res, 2006; 222(1-2): 1-15.

45. Buss E, Hall JW 3rd, Grose JH, Hatch DR. Perceptual consequences of peripheral hearing loss: do edge effects exist for abrupt cochlear lesions? Hear Res, 1998; 125: 98-108.

46. Nishimura H, Doi K, Iwaki T, Hashikawa K, Oku N, Teratani T i wsp. Neural plasticity detected in short- and long-term cochlear implant users using PET. NeuroReport, 2000; 11: $811-15$. 
47. Naito Y, Iwao H. Verbal self-monitoring in deaf subjects using cochlear implants. Cochlear Implants International, 2000; 1(1): $45-54$.

48. Strelnikov K, Rouger J, Eter E, Lagleyre S, Fraysse B, Demonet JF i wsp. Binaural stimulation through cochlear implants. Otol Neurotol, 2011; 32(8); 1210-17.

49. Giraud AI, Truy E, Frackowiak RS. Imaging plasticity in cochlear implant patients. Audiol Neurootol, 2001; 6: 381-93.

50. Cieśla K. The analysis of PET water activation studies with cochlear implants patients and its optimization for modern PET cameras. Awarded Master of Sciences, University of Manchester, 2011.
51. Lee HJ, Giraud AL, Kang E, Oh SH, Kang H, Kim CS i wsp. Cortical activity at rest predicts cochlear implantation outcome. Cerebral Cortex, 2007; 17: 909-17.

52. Lazard DS, Lee HJ, Giraud A. Bilateral reorganization of posterior temporal cortices in post-lingual deafness and its relation to cochlear implant outcome. Hum Brain Mapp, 2013; 34(5): 1208-19.

53. Tibbetts K, Ead B, Umansky A, Coalson R, Schlaggar BL, Firszt $J B$ i wsp. Interregional brain interactions in children with unilateral hearing loss. Otolaryngol Head Neck Surg, 2011; 144(4): 602-11.

54. Edeline JM. Beyond traditional approaches to understanding the functional role of nueromodulators in sensory cortices. Front Behav Neurosci, 2012; 6(45). 